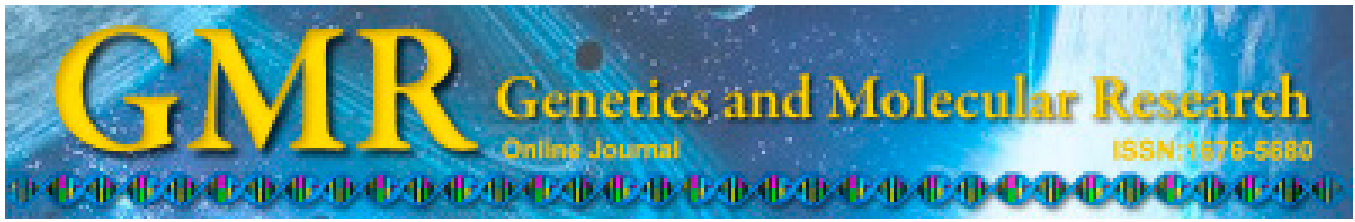

\title{
Genetic variation detected by RAPD markers in natural populations of babassu palm (Attalea speciosa Mart.)
}

\author{
M.F. Santos ${ }^{1}$, K.J. Damasceno-Silva ${ }^{2}$, M.A. Carvalhaes ${ }^{2}$ and P.S.C. Lima ${ }^{2}$ \\ ${ }^{1}$ Genética e Melhoramento, Universidade Federal do Piauí, \\ Campus Senador Helvídio Nunes de Barros, Picos, PI, Brasil \\ ${ }^{2}$ Embrapa Meio-Norte, Teresina, PI, Brasil \\ Corresponding author: K.J. Damasceno-Silva \\ E-mail: kaesel.damasceno@embrapa.br
}

Genet. Mol. Res. 14 (2): 6124-6135 (2015)

Received July 21, 2014

Accepted December 5, 2014

Published June 8, 2015

DOI http://dx.doi.org/10.4238/2015.June.8.10

\begin{abstract}
The purpose of this study was to analyze the effects of management on the genetic structure of natural populations of Attalea speciosa in the State of Piauí, Brazil, using randomamplified polymorphic DNA (RAPD) markers. Three babassu populations under different management systems were selected. Polymerase chain reactions were performed for 20 RAPD primers. A total of 146 bands were generated, 141 of which were polymorphic $(96.58 \%)$, with a variation of 4 and 12 loci and an average of 7 bands per primer. A dendrogram revealed a clear separation between the three populations (0.57). Data reliability and node consistency were verified by bootstrap values and the cophenetic correlation coefficient $(88.15 \%)$. Coefficients of similarity between pairs of genotypes ranged from 0.26 to 0.86 , with a mean of 0.57 . Nei's genetic diversity index $\left(H_{\mathrm{E}}\right)$ value of the population sampled in Teresina was 0.212 , of Esperantina it was 0.195, and of José de Freitas it was 0.207. After the $H_{\mathrm{E}}$ was decomposed, the complete diversity was found to be 0.3213 . Genetic differentiation between populations was
\end{abstract}


0.362 , and the estimation of gene flow between populations was low (0.879). Analysis of molecular variance revealed that $59.52 \%$ of the variation was contained within populations, and $40.48 \%$ was between populations. RAPD markers were effective for genetic diversity analysis within and between natural babassu populations, and exhibited a high level of polymorphism. Genetic diversity was the highest within populations; variability was lower in the managed populations than in the undisturbed populations.

Key words: Genetic diversity; Population management; Palm tree; Similarity coefficients

\section{INTRODUCTION}

The babassu palm, Attalea speciosa Mart., is a pioneer and a dominant species, and generally grows at a low density in native vegetation (Peters et al., 1989; Anderson et al., 1995), and its presence is strongly associated with anthropically disturbed areas (Ribeiro and Walter, 1998). Silva (2008) claimed that the distribution of babassu palms in disturbed areas is extremely variable, and is affected in diversity, density, and concentration by the management system employed.

Human population growth and the consequent pressure on natural resources have made extraction in its rudimentary form economically unviable, requiring techniques and methodologies that facilitate multiple uses of the forest, disclosing possibilities of economic exploitation (Santos et al., 2003). Non-timber products are often the basis for artisanal and small-scale industrial production (Arnold and Pérez, 1995). The management of natural populations should also consider the genetic constitution of the individuals for the exploitation of a target species, which is partly responsible for differences in yield, adaptation, and reproduction among individuals of a species (C-Neto, 2004), by causing variations in population size and spatial patterns within populations (Bawa and Krugman, 1990; Murawsky, 1995).

Information on their genetic constitution is essential to understand the genetic structure of these native populations, and therefore for the design of conservation strategies, improvement and sustainable management with activities aimed at defining reserve size, the appropriate management of the species, to restore degraded areas, and to collect seeds for planting native species (Kageyama et al., 2003). Therefore, knowledge of the variability between natural $A$. speciosa populations is important for plant breeding, preservation, and adequate management.

Genetic markers are widely used in the conservation of genetic forest resources, e.g., in the measurement of diversity and genetic diversity in natural and managed populations, the estimation of gene flow or migration rate, and the characterization of the reproductive system (Glaubitz and Moran, 2000). Adin et al. (2004) used amplified fragment length polymorphism (AFLP) molecular markers to compare genetic diversity and trading between populations of domesticated palms (Bactris gasipaes Kunth) in the Peruvian Amazon. The genetic diversity was 0.262 in populations of the indigenous communities and 0.253 in migrant communities; the genetic differentiation $\left(G_{\mathrm{ST}}\right)$ between populations was 0.037-0.041 $(\mathrm{P}<0.01)$, with no correlation between genetic differentiation and the geographic locations of the populations.

Sawazaki et al. (1998) studied genetic variability and ecotypes in the genera Euterpe, 
Bactris, Elaeis, and Syagrus. In a comparison between isozyme and random-amplified polymorphic DNA (RAPD) markers, the authors found the latter to be more efficient since it allowed the analysis of a high number of genetic markers, in addition to detecting the similarity between ecotypes and/or species distributed according to the geographical regions of their natural occurrence.

Despite the importance of $A$. specios $a$ and the economic interest in the crop, this is the first study to assess the level of genetic diversity and species distribution in natural babassu populations under different management systems. In a study of the genetic similarity between accessions of the active or living GenBank (BAG) of babassu palm of Embrapa Meio-Norte using RAPD markers, Santos et al. (2008) observed variability between genotypes, with similarity coefficients ranging from 0.53 to 0.82 . Souza et al. (2008) tested the effectiveness of inter-simple sequence repeat (ISSR) and RAPD markers for the analysis of genetic variability in this species, and observed that both marker types were effective in determining the genetic relationships among babassu palm genotypes.

In view of the current state of depletion of many babassu forests and populations, characterization studies of genetic variability are fundamental. Therefore, the objective of the present study was to identify the genetic variation within and between the populations of $A$. speciosa under different management intensities, and to evaluate the effects of different levels of exploitation on the genetic diversity of the populations, in order to provide information for establishing guidelines for the management and conservation of this species.

\section{MATERIAL AND METHODS}

We studied three natural populations of $A$. speciosa under different management systems in the municipalities of Teresina, Esperantina and Jose de Freitas, in the State of Piauí, Brazil. Twenty trees per population were selected for data collection, and were labeled according to the municipality: Teresina (T1, T2,...T19, and T20), Esperantina (E21, E22,..., E39, and E40), and Joseph de Freitas (JF41, JF42,..., JF59, and JF60).

The population labeled T was from Teresina (with a total area of $1.312 \mathrm{~km}^{2}$, or $0.55 \%$ of the state area; $5^{\circ} 5^{\prime} 21 " \mathrm{~S}, 42^{\circ} 48^{\prime} 07^{\prime \prime} \mathrm{W} ; 72 \mathrm{~m}$ above mean sea level, AMSL). The climate is hot, sub-humid tropical, with dry periods of 6 months and temperatures ranging from $22^{\circ}$ to $38^{\circ} \mathrm{C}$, with an average annual rainfall of $1377.7 \mathrm{~mm}$ (Senplan, 2011). The sample population in this municipality belonged to an area of Embrapa Meio-Norte, and is exploited at a lowintensity level.

Population E was in the municipality of Esperantina, in a forest area designated for fruit collection. This activity is a source of income for many families in the region, particularly those of the babassu nut breakers, which typify the intense and longstanding tradition of fruit collection in the area. The area is irregularly shaped, and contains $922.38 \mathrm{~km}^{2}\left(03^{\circ} 54^{\prime} 06^{\prime}\right.$ 'S, 42 ${ }^{\circ} 14^{\prime} 01^{\prime \prime} \mathrm{W} ; 59 \mathrm{~m}$ AMSL). It is covered with mixed deciduous forest vegetation, with patches of Caatinga (semi-arid vegetation) and Cerrado (savanna vegetation). The climate is sub-humid tropical, with a dry period of 6 months and temperatures of between $25^{\circ}$ and $34^{\circ} \mathrm{C}$, with an average annual rainfall of $1493.0 \mathrm{~mm}$.

Population JF was in the municipality of José de Freitas (with a total area of 1632.70

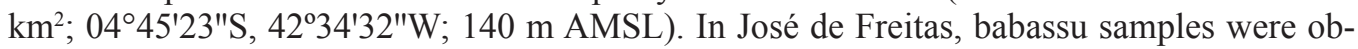
tained from an area of approximately 1200 ha, in the Nazareth Eco Resort. This area is largely undisturbed, and has been isolated from human activity for many years. The regional vegeta- 
tion consists of semi-deciduous forests with patches of Caatinga, Cerrado, and babassu palm forests. The climate is hot, semi-arid tropical, with a dry period of 6 months and temperatures of between $18^{\circ}$ and $38^{\circ} \mathrm{C}$. It is an area free of human influence, where all vegetation is conserved (Senplan, 2011).

Leaves were collected from 20 selected trees (minimum distance between trees, $50 \mathrm{~m}$ ) that were in the fully reproductive stage, from each population, using a simple-randomized sampling. All the material collected was packed in plastic bags, labeled, and stored in ice chests. The material was then taken to the Laboratory of Molecular Biology and Biotechnology of Embrapa MeioNorte, where the leaf tissues were frozen, to prevent enzyme degradation prior to DNA extraction.

Approximately $100 \mathrm{mg}$ leaf tissue from young and healthy leaves from each plant of the three populations was used for the extraction of genetic material. DNA was extracted following the manufacturer protocol, using an Invisorb ${ }^{\circledR}$ Spin DNA Extraction Kit. The fresh plant tissue was ground in a Precellys ${ }^{\circledR} 24$ homogenizer, in 2.0-mL tubes containing five glass beads (with a diameter of $3 \mathrm{~mm}$ ) and buffer from the purification kit. The DNA was quantified on $0.8 \%$ agarose gel in $0.5 \mathrm{X}$ Tris-Borate-EDTA (TBE) buffer, stained with Biotium GelRed ${ }^{\mathrm{TM}}$ Nucleic Acid Stain, and diluted to 10,000X in water, for a comparison of the resolution of DNA samples with a DNA ladder at a concentration of $100 \mathrm{ng}$. The quality and quantity of the extracted DNA were recorded using a NanoDrop ${ }^{\mathrm{TM}}$ spectrophotometer, using $2 \mu \mathrm{L}$ of the extracted sample. The DNA samples were diluted in TE buffer at a concentration of $15 \mathrm{ng} / \mu \mathrm{L}$, for use in a polymerase chain reaction analysis.

One hundred primers (Operon Technologies, series A, K, M, N, and P) were evaluated, which were applied to DNA samples of three trees per population. At this step, we tried to select primers that amplified the highest number of polymorphic markers, and had good reading quality.

To analyze the genetic diversity of the populations, the 20 primers with the best polymorphisms were used. The amplification reactions were performed according to a modified protocol of Williams et al. (1990). The final volume used in the reactions was $20 \mu \mathrm{L}$, and contained the following components: $10 \mathrm{X}$ buffer (16.65 mM Tris- $\mathrm{HCl}, \mathrm{pH} 8.0), 83.25 \mathrm{mM} \mathrm{KCl}$, $2.5 \mathrm{mM} \mathrm{MgCl}$ (New England), $0.8 \mathrm{mM}$ dNTP (Invitrogen), $0.2 \mu \mathrm{M}$ primer, $1 \mathrm{U}$ Taq DNA polymerase (New England), $1 \mu \mathrm{L}$ genomic DNA ( 15 ng), and ultrapure $\mathrm{H}_{2} \mathrm{O}$. Amplifications were carried out in a Veriti ${ }^{\circledR}$ 96-Well Thermal Cycler (Applied Biosystems), with an initial denaturation step of $1 \mathrm{~min}$ at $92^{\circ} \mathrm{C}$, followed by 45 cycles of $1 \mathrm{~min}$ at $92^{\circ} \mathrm{C}$ for denaturation, 1 min at $35^{\circ} \mathrm{C}$ for annealing, $2 \mathrm{~min}$ at $72^{\circ} \mathrm{C}$ for extension, and a final extension of $5 \mathrm{~min}$ at $72^{\circ} \mathrm{C}$. The amplification products were electrophoresed on $1.5 \%$ agarose gel, buffered, and revealed using GelRed ${ }^{\mathbb{B}}$ (Biotium). The gels were then photographed under an ultraviolet transilluminator (MiniBIS-Pro, DNR Bio-Imaging Systems), and the bands counted. The bands of amplified fragments were coded as random binary characters $(0$ and 1$)$, corresponding to the absence or presence of bands, respectively. From these data, we estimated the genetic similarity between genotypes of the three sampled populations, using the Jaccard similarity coefficient, calculated using PAST version 1.34 (Hammer et al., 2001). From the resulting similarity matrix, a grouping analysis was performed by the unweighted pair-group method, using arithmetic averages (UPGMA), using the same program. The cophenetic correlation coefficient $(r)$ was calculated based on the similarity matrix and a dendrogram. From the binary matrix of the amplified fragments, the bootstrap reliability index was calculated and a dendrogram was constructed, based on data from 5000 permutations. To evaluate the adherence between the dendrogram and the Jaccard similarity matrix, the cophenetic correlation of Mantel was estimated, using 
PAST v.1.34 (Hammer et al., 2001).

The genetic similarities were estimated using the Jaccard coefficient, with the cutoffpoint based on the estimate of the mean genetic similarity:

$$
s g_{m}=\sum s g_{i j} / N
$$

where $s g_{i j}$ is the genetic similarity between each pair of individuals and $N$ is the number of pairs obtained. For the intra- and inter-population analyses of $A$. speciosa, the program POPGENE (population genetic analysis) version 1.32 (Yeh et al., 2000) was used, with parameters set for diploid-dominant data. The following descriptive statistics were calculated: the number and percentage of polymorphic loci; Nei's gene diversity $(1973)\left(H_{\mathrm{E}}\right)$; the Shannon index $\left(H_{\mathrm{O}}\right)$; the total diversity $\left(H_{\mathrm{T}}\right)$, estimated from the mean allele frequency per locus; the component of diversity within the population, and the component of diversity between populations within a species; and genetic differentiation between populations $\left(G_{\mathrm{ST}}\right)$. Analysis of molecular variance was performed using the program Arlequin version 3.1 (Excoffier, 2006), by a total decomposition of the variance components, between and within populations. The variance components were tested using the coefficient $\phi_{\mathrm{ST}}$.

\section{RESULTS}

Based on 20 RAPD primers, a total of 146 bands were detected, 141 of which were polymorphic (96.58\%; Table 1). Variation between 4 and 12 polymorphic loci was observed, with a mean of 7 bands per primer. The high polymorphism between genotypes was clearly demonstrated by the RAPD band patterns obtained using the primer OP-K19 (Figure 1).

Table 1. Selected Random Amplified Polymorphic DNA (RAPD) primers, with their respective sequences and number of amplified and polymorphic fragments.

\begin{tabular}{|c|c|c|c|}
\hline \multirow[t]{2}{*}{ Primer } & \multirow[t]{2}{*}{ Nucleotide sequence } & \multicolumn{2}{|c|}{ No. of fragments } \\
\hline & & Amplified & Polymorphic \\
\hline OP-K15 & 5'-CTCCTGCCAA-3' & 8 & 8 \\
\hline OP-K19 & 5'-CACAGGCGGA-3' & 7 & 5 \\
\hline OP-M01 & 5'-GTTGGTGGCT-3' & 4 & 3 \\
\hline OP-M05 & 5'-GGGAACGTGT-3' & 6 & 6 \\
\hline OP-M09 & 5'-GTCTTGCGGA-3' & 9 & 9 \\
\hline OP-M12 & 5'-GGGACGTTGG-3' & 6 & 6 \\
\hline OP-M14 & 5'-AGGGTCGTTC-3' & 7 & 7 \\
\hline OP-M16 & 5'-GTAACCAGCC-3' & 8 & 8 \\
\hline OP-M18 & 5'-CACCATCCGT-3' & 7 & 7 \\
\hline OP-N02 & 5'-ACCAGGGGCA-3' & 12 & 12 \\
\hline OP-N03 & 5'-GGTACTCCCC-3' & 6 & 6 \\
\hline OP-N04 & 5'-GACCGACCCA-3' & 5 & 5 \\
\hline OP-N06 & 5'-GAGACGCACA-3' & 9 & 8 \\
\hline OP-N09 & 5'-TGCCGGCTTG-3' & 12 & 12 \\
\hline OP-N10 & 5'-ACAACTGGGG-3' & 9 & 9 \\
\hline OP-N11 & 5'-TCGCCGCAAA-3' & 5 & 5 \\
\hline OP-N12 & 5'-CACAGACACC-3' & 7 & 7 \\
\hline OP-N15 & 5'-CAGCGACTGT-3' & 8 & 8 \\
\hline OP-P03 & 5'-CTGATACGCC-3' & 5 & 5 \\
\hline OP-P04 & 5'-GTGTCTCAGG-3' & 6 & 5 \\
\hline Total & & 146 & 141 \\
\hline
\end{tabular}




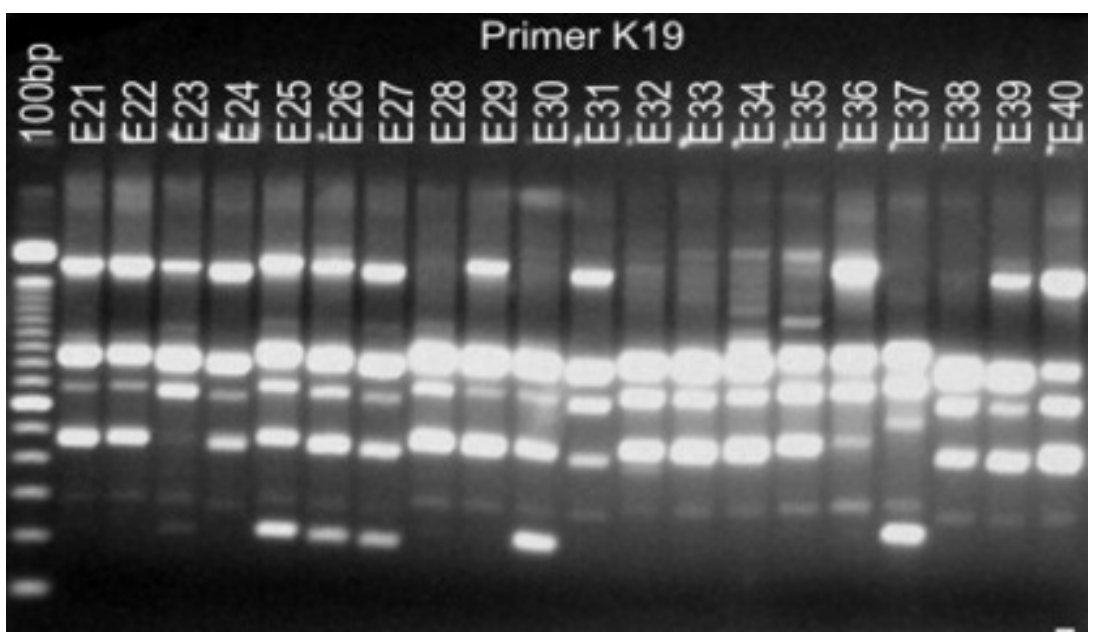

Figure 1. Electrophoretic profile obtained by DNA amplification of 20 plants of Attalea speciosa Mart. from a population in Esperantina, Brazil, using the primer OP-K19.

Of the RAPD primers used in this study, the ones that produced at least eight or more polymorphic bands are recommended for the analysis of genetic variability in the babassu palm, namely, M09-OP, OP-N02, N06-OP, OP-N09, and N10-OP.

The similarity matrix, using the Jaccard coefficient between genotypes based on RAPD markers, exhibited coefficients of similarity between pairs of genotypes that ranged from 0.16 to 0.75 , with a mean of 0.41 . The greatest similarity was found between the individuals 21 and 22 of population E, while the greatest dissimilarity was observed in the pairs formed by plants 23 and 30 of population E with plant 49 of population JF. The RAPD markers allowed the genetic differentiation of three populations of A. speciosa (Figure 2). The dendrogram clearly differentiated the three populations $(0.41)$. The populations $\mathrm{T}$ and $\mathrm{E}$, in two areas managed by fruit collection, were rather similar, while the population JF, located in a conserved area with no type of management, was distant from the other populations. The data reliability and consistency of the nodes were verified by bootstrap values, and the value of the cophenetic correlation coefficient was $90.13 \%$. The matrices of the three populations were correlated by the Mantel test and revealed a coefficient of $r=-0.0161$, indicating that the arrays were not correlated, confirming the results obtained by the dendrogram.

The estimates of genetic diversity indices are shown in Table $2 . H_{\mathrm{E}}$ was 0.212 for population T, 0.195 for population E, and 0.207 for population JF. The genetic diversity of the undisturbed population in José de Freitas was higher than that of population E, where the management of fruit collection is intensive. Depending on the magnitude, the removal of fruits in populations can alter the levels of genetic diversity. The results show that genetic variability was lower in the managed population, due to the exclusion of some genotypes and the consequent loss of alleles. The estimated values for $H_{\mathrm{O}}$ showed high genetic diversity between and within populations, with 0.336 for population $\mathrm{T}, 0.302$ for population $\mathrm{E}, 0.322$ for population $\mathrm{JF}$, and 0.485 for all populations, being very similar in the three populations (the Shannon index ranges from 0 to 1 , and the closer the value is to zero, the lower is the diversity). The population with the lowest diversity level was the one under intensive management, which can lead to genetic erosion. 


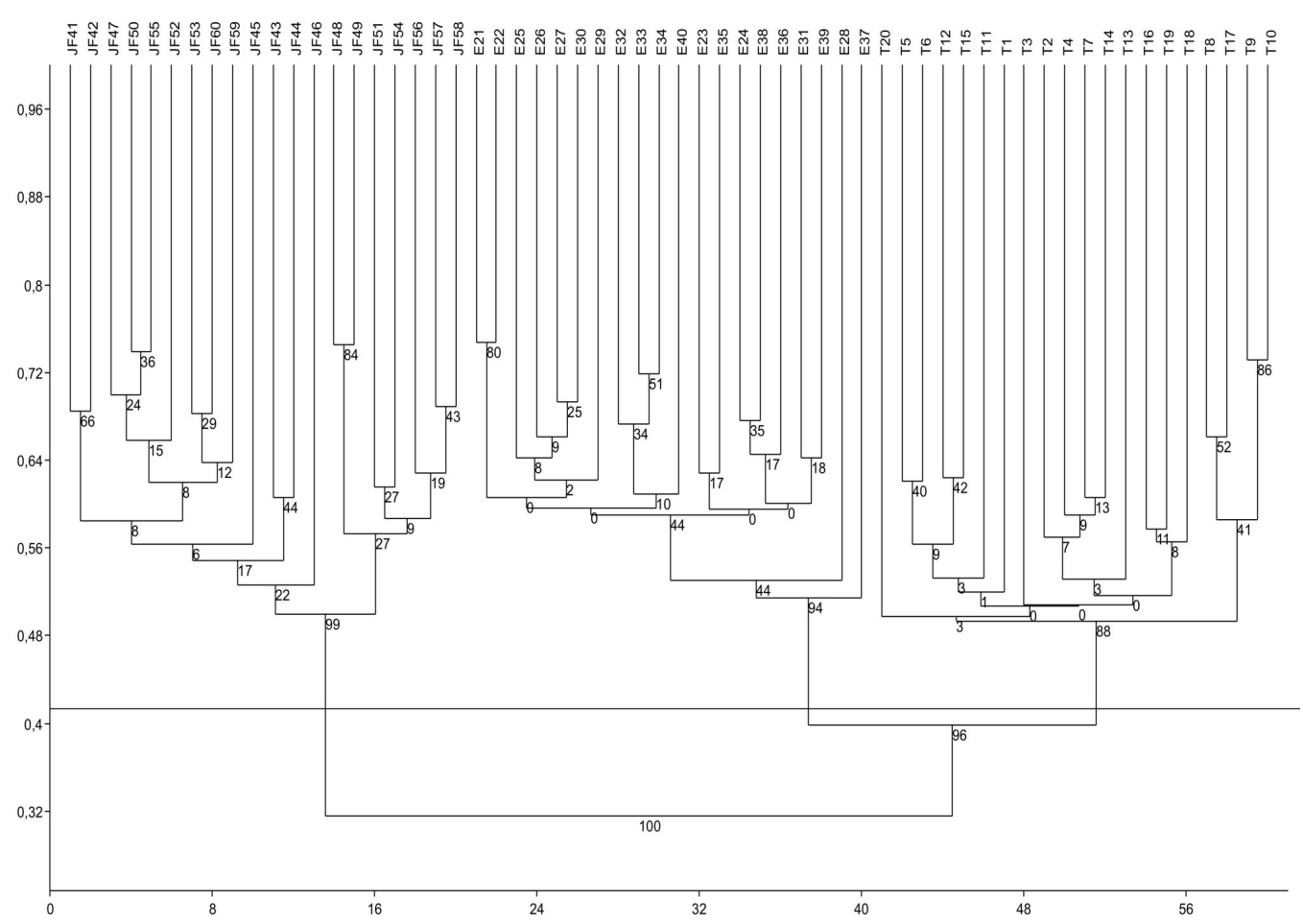

Figure 2. Dendrogram constructed based on the genetic similarities between 60 plants of Attalea speciosa Mart. using the Jaccard similarity index and the UPGMA clustering method. Teresina (T), Esperantina (E), José de Freitas (JF).

Table 2. Indices of genetic diversity of three populations of Attalea speciosa Mart.

\begin{tabular}{lcc}
\hline Populations & $H_{\mathrm{E}}$ & $H_{\mathrm{O}}$ \\
\hline Teresina & 0.212 & 0.336 \\
Esperantina & 0.195 & 0.302 \\
José de Freitas & 0.207 & 0.322 \\
Set of populations & 0.321 & 0.485 \\
\hline
\end{tabular}

$H_{\mathrm{E}}$, genetic diversity of Nei; $H_{\mathrm{O}}$, Shannon index.

The highest percentage of polymorphic loci was observed in population $\mathrm{T}$, an area where management was not intense, and the lowest was observed in population E (Table 3), which was under intensive management. On average, 106.33 polymorphic loci were obtained. The low percentage of polymorphic loci in population $\mathrm{E}$ was due to intensive fruit collection in the region, resulting in a loss of variability.

Table 3. Number and percentage of polymorphic loci.

\begin{tabular}{lcr}
\hline Municipality & No. of polymorphic loci & \% of polymorphic loci \\
\hline Teresina & 117 & 80.14 \\
Esperantina & 97 & 66.44 \\
José de Freitas & 105 & 71.92 \\
Mean & 106.33 & 72.83 \\
\hline
\end{tabular}


The distribution of genetic variation within and between populations was calculated as described by Nei (1978; Table 4). The $G_{\mathrm{ST}}$ was 0.362 , indicating that $36.2 \%$ of the genetic variability was found between populations and $63.8 \%$ was found within populations. The $G_{\mathrm{ST}}$ is a widely used statistical measure of genetic differentiation, because it is not affected by the reproduction system of the species, nor the number of alleles per locus, or the actions of evolutionary forces (migration, selection, and mutation) (Nei, 1973). The high genetic diversity found between populations may be associated with the reproductive isolation of the populations.

The $H_{\mathrm{T}}$ was relatively high $(0.321)$, indicating that $32.1 \%$ of the genotypes were unique, showing a reserve of genetic variability of this species in these populations. The estimation of gene flow between the three A. speciosa populations was low (0.879). Estimates of gene flow are not easy to interpret. According to Wright (1931), gene flow values below 1.0 indicate genetic isolation. The low value found in this study demonstrated that isolation caused by genetic drift is already occurring, showing the need to initiate the implementation of conservation strategies for the species.

\begin{tabular}{|c|c|c|c|c|}
\hline & $H_{\mathrm{T}}$ & $H_{\mathrm{S}}$ & $G_{\mathrm{ST}}$ & $N_{\mathrm{m}}$ \\
\hline Mean & 0.321 & 0.204 & 0.362 & 0.878 \\
\hline Standard deviation & 0.021 & 0.013 & & - \\
\hline
\end{tabular}

$H_{\mathrm{T}}$, heterozygosity; $H_{\mathrm{S}}$, mean genetic diversity within populations; $G_{\mathrm{ST}}$, genetic diversity between populations; $N_{\mathrm{m}}$, gene flow.

Genetic differentiation between the sampled populations was highly significant ( $\phi_{\mathrm{ST}}=0.4048, \mathrm{P}<0.001$ ), corresponding to $40.48 \%$ of the total genetic variation, indicating relatively high levels of genetic differentiation between the three populations. These results were expected, because the intensities of management were different. Nevertheless, it appears that much of the variation was retained at the sampling locations, evidencing wide variability among the genotypes of each population $(59.52 \%)$, which can be explained by the management systems at each site, the influence of human activity on allele exchange, as well as by pollen dispersal within populations. A summary of analysis of molecular variance is presented in Table 5 .

Table 5. Summary of analysis of molecular variance for the three populations of Attalea speciosa Mart.

\begin{tabular}{lrrrrrr}
\hline Source of variation & d.f. & SS & Comp. de variance & \% Total & $\Phi_{\text {ST }}$ \\
\hline Between populations & 2 & 541.717 & 12.6155 & 40.48 & 0.4048 \\
Within populations & 57 & 1057.150 & 18.5464 & 59.52 & 0.001 \\
Mean & 59 & 1598.867 & 31.16208 & 100.00 & \\
\hline
\end{tabular}

d.f., degrees of freedom; SS, sum of squares.

\section{DISCUSSION}

The high polymorphism detected in this study (96.58\%) among palm trees of the three babassu populations by RAPD markers may be related to the development of natural hybrids resulting from intraspecific crosses that occurred in this species (Anderson and Balick, 1988), or because the species has a mixed mating system and is not yet domesticated. 
Similar results were reported in the germplasm of the açaí palm (Euterpe oleracea Mart.) by Oliveira et al. (2007), where 28 selected simple sequence repeat primers generated 263 amplification products, $100 \%$ of which were polymorphic. The authors attributed the high degree of polymorphism to the fact that the species is monoecious, allogamous, and is currently being domesticated.

The RAPD technique has been used in the molecular characterization and quantification of genetic variability in several palm species. Nunes et al. (2008) conducted a study on the pindo palm (Butia capitata) using RAPD markers and obtained a similar number of fragments (136), 77 of which were polymorphic. In the genetic characterization of the peach palm (Bactris gasipaes Kunth.) cultivated in southern Bahia, Brazil, Isensse et al. (2007) detected 46 polymorphic genetic markers using RAPD, fewer than that found in the present study. Sawazaki et al. (1998), however, tested 40 primers in palm trees belonging to the genera Euterpe, Bactris, Elaeis, and Syagrus, and found a total of 256 polymorphic bands. The results of this study show that RAPD markers are effective in detecting polymorphisms.

Souza et al. (2008) studied the effectiveness of RAPD and ISSR markers for the babassu palm and obtained 21 loci, 13 of which were polymorphic, using RAPD markers; and 72 loci, 45 of which were polymorphic, using ISSR markers, demonstrating the efficacy of both markers in determining genetic relationships among genotypes.

A high genetic diversity among the babassu genotypes was observed. The genetic similarities were equal to or higher than the general mean in $46.04 \%$ of the pairs of genotypes, revealing a high genetic similarity between the babassu genotypes. A similar result was reported by Oliveira et al. (2007) for the açaí palm, who reported genetic similarities equal to or higher than the general mean in $43.97 \%$ of the pairs of genotypes. The high value found in the babassu palm confirms the existence of great diversity among the genotypes of the three populations.

The genetic differentiation between the three A. speciosa populations shown in the dendrogram indicates that no allele exchange occurred, probably because of the geographical distance between the populations, since the main mechanism of pollen dispersal in this species occurs via a beetle from the family Nitidulidae, Mystrops mexicana (Henderson et al., 1995).

The levels of $H_{\mathrm{E}}$ present in the three populations (Table 2) can be considered high when compared with levels in other tree species. Hamrick and Godt (1990) analyzed information from 449 species, and estimated an $H_{\mathrm{E}}$ of 0.157 in species with entomophilous pollination. Similar results were reported by Sebbenn et al. (2001), in a comparison between the levels of genetic diversity in natural and managed populations, and found an average $H_{\mathrm{E}}$ of 0.314 for the natural and 0.266 for the managed populations, as was found in the present study. The Shannon index measures the degree of genetic similarity between plants, and the lower the value, the lower the diversity. In this study, the value for this index was high and very similar in the three populations, i.e., there was great diversity among them, confirmed by the high level of polymorphic loci in the three populations. The Shannon indices and the percentage of polymorphic loci were lowest in population $\mathrm{E}$, which was under intensive management. Sebbenn et al. (2001) compared the levels of genetic diversity between a natural and a managed population, and found that the percentage of polymorphic loci was high in the natural and low in the managed populations ( 84.6 and $76.9 \%$, respectively). Zimback et al. (2004) showed that unsustainable management leads to a loss of variability, and found high values of polymorphic loci in the analysis of the genetic structure of Trichilia pallida Swartz populations using RAPD markers. This result shows that the populations had not been isolated from each other, so the small differences between them may be due to genetic drift at each location. 
The distribution of genetic variation within and between populations revealed that $63.8 \%$ of the genetic variation was within populations and $36.2 \%$ was between populations. The cause of the high genetic divergence between populations was associated with their reproductive isolation. Hamrick and Godt (1990) analyzed information from 449 species, and concluded that perennial species with long life cycles, that predominantly sexually reproduce by cross-fertilization, and that have wide geographic distributions accumulate greater genetic variation within their populations, with low population differentiation. Sebbenn et al. (2001) studied the effects of management on the genetic structure of natural populations of Tabebuia cassinoides, and found high genetic variability within populations (96.9\%), showing that tropical tree species with mixed reproductive or mating systems maintain the highest variability within populations. Silva (2006) studied the genetic diversity and structure of natural palm populations of Geonoma schottiana Mart., and reported a value of $86.5 \%$ within populations, suggesting high variability within populations; in woody species, genetic variation is generally greatest within populations (Aagard et al., 1998).

The high value obtained for $H_{\mathrm{T}}$ shows that in these populations the species has a reserve of genetic variability. A similar result was obtained by Mendonça (2006) in an analysis of the genetic diversity of Calophyllum brasiliense Camb., who obtained a high value of $H_{\mathrm{T}}$ (0.402). According to Hamrick and Godt (1990), one can expect high levels of total genetic diversity in tree species with a long-life cycle, a mixed mating system, an efficient mechanism of pollen and seed dispersal, and with a wide geographical distribution. Since the babassu palm has these characteristics, a high genetic diversity was expected.

The gene flow for the babassu populations was low (0.879). Note that gene flow values below 1 correspond to the occurrence of genetic isolation (Wright, 1931), indicating the need to initiate the implementation of conservation strategies for the species. Gene flow both within and between populations depends, of course, on the reproductive structure. The babassu palm has a mixed mating system, with a predominance of cross-fertilization, and is mostly pollinated by the nitidulid beetle M. mexicana (Anderson and Balick, 1988; Anderson et al., 1988). Therefore, the gene flow result can be explained by the distance between the three populations, which prevented allelic exchange between them.

The genetic differentiation between populations was $40.48 \%$, which was slightly less than the variation between the genotypes of each population $(59.52 \%)$. This greater variation within populations can be explained by the mechanism of pollen dispersal within populations. Oliveira and Silva (2008) studied genetic differentiation among açaí palm progenies using RAPD markers, and found that $75.85 \%$ of the genetic variability was between accessions of each origin and $30.12 \%$ was between accessions. Similar results have been recorded in natural populations of Euterpe edulis (Cardoso et al., 2000), using AFLP, and peach palm races by RAPD markers (Rodrigues et al., 2004), and both were dominant, i.e., the genetic differentiation in palms is high, and variability is greatest within populations.

According to Bawa (1992), tropical woody plants that predominantly cross-fertilize may differ in the percentage of genetic differentiation between populations, depending on the species. Analysis of molecular variance has been conducted to determine levels of genetic differentiation in palm germplasm (populations, types, ecotypes, etc.) conserved in gene banks and/or germplasm collections, based on different classes of molecular markers (Cardoso et al., 2000). However, no studies have been conducted on the grouping of palms belonging to the species $A$. speciosa Mart., maintained in germplasm collections or in natural populations. 


\section{REFERENCES}

Aagaard JE, Krutovskii KV and Strauss SH (1998). RAPDs and allozymes exhibit similar levels of diversity and differentiations among populations and races of Douglas-fir. Heredity 81: 69-78.

Adin A, Weber C, Montes CS, Vidaurre H, et al. (2004). Genetic differentiation and trade among populations of peach palm (Bactris gasipaes Kunth) in the Peruvian Amazon implications for genetic resource management. Theor. Appl. Genet. 108: 1564-1573.

Anderson AB and Balick MJ (1988). Taxonomy of babassu complex (Orbignya ssp. Palmae). System. Bot. 13: 32-50.

Anderson AB, May PH and Balick MJ (1995). The subsidy from nature: palm forests, peasantry and development on the Amazon frontier. Columbia University, New York.

Anderson AB, Overal WL and Henderson A (1988). Pollination ecology of a forest dominant palm (Orbignya phalerata Mart.) in Northern Brazil. Biotropica 20: 192-205.

Arnold JE and Pérez MR (1995). Framing the issues relating to non-timber forest products research. In: Current issues in non-timber forest products (Arnold JE and Pérez MR, eds.). CIFOR.

Bawa KS (1992). Mating systems, genetic differentiation and speciation in tropical rain forest trees. Biotropica 24: 250-255.

Bawa KS and Krugman SL (1990). Reproductive biology and genetics of tropical trees in relations to conservation and management. In: Rain forest regeneration and management (Gomes-Pompa A, Whitmore TC and Hadley M, eds.). UNESCO, Paris, cop 6, 119-136.

Cardoso SRS, Eloy NB, Provan J, Cardoso MA, et al. (2000). Genetic differentiation of Euterpe edulis Mart. populations estimated by AFLP analysis. Mol. Ecol. 9: 1753-1760.

C-Neto M (2004). Efeito do manejo na diversidade genética de populações naturais de Tabebuia cassinoide Lan (DC) por marcadores isoenzimáticos. Dissertação (Mestrado), ESALQ, Piracicaba.

Excoffier L (2006). Arlequin: Computational and Molecular Population Genetics Lab CMPG. Version 3.01. Zoological Institute, University of Berne, Berne.

Glaubitz JC and Moran GF (2000). Genit tools: the use of biochemical and molecular markers: In: Forest conservation genetics: principles and practice (Young A, Boshier D and Boyle T, eds.). CSIRO, Collingwood, 39-59.

Hammer O, Harper DAT and Ryan PDR (2001). PAST: Paleontological statistics software package for education and data analysis. Palaeontol. Electron. 4: 9.

Hamrick JL and Godt MJW (1990). Allozyme diversity in plant species. In: Plant population genetics, breeding, and genetic resources (Brown AHD, Clegg MT, Kahler AL and Weir BS, eds.). Sinauer, Sunderland, 43-63.

Henderson A, Galeano G and Bernal R (1995). Field guide to the palms of the Americas. Princeton University, New Jersey, 166-167.

Isensse JMF, Vidal PO and Gaiotto FA (2007). Caracterização genética entre pupunheiras cultivadas no sul da Bahia por marcadores RAPD. Magistra, Cruz das Almas 19: 304-310.

Kageyama PY, Cunha GC, Barreto KD, Gandara FB, et al. (2003). Diversidade e autocorrelação genética espacial em populações de Ocotea adorifera (Lauraceae). Sci. Forest. 64: 108-119.

Mendonça EG (2006). Análise da diversidade genética de Calophyllum brasiliense Camb. por marcadores RAPD em populações de Mata Ciliar/Evânia Galvão Mendonça. UFLA, Lavras, 67.

Murawsky DA (1995). Reproductive biology and genetics of tropical trees from a canopy perspective. In: Forest canopies (Lowman MD and Nadkarni NM, eds.). Academic Press, New York, 457-493.

Nei M (1973). Analysis of gene diversity in subdivided populations. Proc. Natl. Acad. Sci. U S A 70: 3321-3323.

Nei M (1978). Estimation of average heterozygosity and genetic distance from a small number of individuals. Genetics 89: 583-90.

Nunes AM, Bianchi VJ, Fachinello JC, Carvalho AZ, et al. (2008). Caracterização molecular de butiazeiro por marcadores RAPD. Rev. Bras. Frutic. 30: 702-707.

Oliveira MSP and Silva KJD (2008). Diferenciação genética entre procedências de açaizeiro por marcadores RAPD e SSR. Rev. Bras. Frutic. 30: 438-443.

Oliveira MSP, Amorim EP, Santos JB and Ferreira DF (2007). Diversidade Genética entre acessos de açaizeiro baseada em marcadores RAPD. Ciên. Agrotec. 31: 1645-1653.

Peters C, Balick MJ, Kahn F and Anderson A (1989). Oligarchic forest of economic plants in Amazonia: Utilization and conservation of an important tropical resource. Conserv. Biol. 3: 342-349.

Ribeiro JF and Walter RMT (1998). Fitofisionomia do bioma Cerrado. In: Cerrado: ambiente e flora (Sano SM and Almeida SP, eds.). EMBRAPA-CPAC, Planaltina, 86-166.

Rodrigues DP, Astolfi-Filho S and Clement CR (2004). Molecular marker-mediated validation of morphologically defined landraces of Pejibaye (Bactris gasipaes) and their phylogenetic relationships. Genet. Resour. Crop Ev. 51: 871-882.

Genetics and Molecular Research 14 (2): 6124-6135 (2015)

CFUNPEC-RP www.funpecrp.com.br 
Santos AJ, Hildebrand E, Pacheco CHP, Pires PTL, et al. (2003). Produtos Não Madeireiros: Conceituação, Classificação, Valoração e Mercados. Ver. Flores 33: 215-224.

Santos MF, Souza IGB, Carvalhaes MA, Araújo ECE, et al. (2008). Similaridade entre genótipos de babaçu (Orbignya phalerata Mart.) estimada por marcadores RAPD. In: I Congresso de Genética do Centro-Oeste, Brasília.

Sawazaki HE, Bovi MLA, Sodek L and Colombo CA (1998). Diversidade genética em palmeiras através de isoenzimas e RAPD. Rev. Bras. Biol. 58: 681-691.

Sebbenn AM, Seoane CES, Kageyama PY and Lacerda CMB (2001). Estrutura genética em populações de Tabebuia cassinoides: implicações para o manejo florestal e a conservação genética. Rev. Inst. Flores 13: 93-113.

Senplan (2011). Banco de Dados de Teresina: Características Gerais. Senplan, Teresina.

Silva CGB (2008). Estado de conservação dos fragmentos florestais na área de proteção ambiental - APA estadual Cachoeira do Urubu (PI) e avaliação de indicadores para monitoração ambiental. Teresina, Dissertação (Mestrado em Desenvolvimento e Meio Ambiente) - Programa Regional de Pós-Graduação em Desenvolvimento e Meio Ambiente (PRODEMA), Universidade Federal do Piauí, Teresina.

Silva MS (2006). Diversidade e estrutura genética em populações naturais de Geonoma schottiana Mart. no Parque Florestal Quedas do Rio Bonito. UFLA, Lavras, 51.

Souza IGB, Santos MF, Sittolin IM, Araújo ECE, et al. (2008). Eficiência dos marcadores RAPD e ISSR para análise da variabilidade genética em babaçu (Orbignya phalerata Mart.). In: I Congresso de Genética do Centro-Oeste, Brasília.

Williams JGK, Kubelik ARK, Livak JL, Rafasla JA, et al. (1990). DNA polymorphisms amplified by arbitrary primers are useful as genetic markers. Nucleic Acids Res. 18: 6531-6535.

Wright S (1931). Evolution in Mendelian populations. Genetics 16: 97-159.

Yeh F, Yanh R and Boyle T (2000). Microsoft windows-based freeware for population genetic analysis, Popgene version 1.31.

Zimback L, Mori ES, Kageyama PY, Veiga RFA, et al. (2004) Estrutura genética de populações de Trichilia pallida Swartz (Meliaceae) por marcadores RAPD. Sci. Fores. 65: 114-119. 